\title{
Nano-scaled Diethylene Triamine Pent Acetic Acid (N-DTPA): Novel Anti-Wilson's Disease Cell Model $\underline{\underline{ }}$
}

\author{
Saba Zakeri ${ }^{1} \underline{\Delta}$, Ehsan Afzal ${ }^{1}$,Parichehr Yaghmaei $^{1}$, Mehdi Mirzaei ${ }^{2}$, Bita Mehravi ${ }^{2}$, Mohammad \\ Reza Aghasadeghi ${ }^{3}$, Massoud Amanlou ${ }^{4}$, Seyed Esmaeil Sadat Ebrahimi ${ }^{4}$, Hassan Namazi ${ }^{5}$, \\ Mohammad Shafiee Alavidjeh ${ }^{4}$, Seyed Davar Siadat ${ }^{3}$, Seyed Ali Delbaz ${ }^{3}$, Seyed Mehdi Sadat ${ }^{3}$, \\ Soheila Hekmat ${ }^{3}$, Mehdi Shafiee Ardestani ${ }^{3,4}$ *
}

${ }^{1}$ Department of Biology, Science and Research Branch, Islamic Azad University, Tehran, Iran

${ }^{2}$ Medical Physics and Biomedical Engineering and Nanomedicine Department, Faculty of Medicine, Shahid Beheshti

Medical University, Tehran, Iran

${ }^{3}$ Hepatitis and AIDS Dept. Pasteur Institute of Iran, Tehran, Iran

${ }^{4}$ Department of Medicinal and Radiopharmaceutical Chemistry, Tehran University of Medical Sciences, Tehran, Iran

${ }^{5}$ Faculty of Chemistry, Laboratory of Natural Carbohydrates and Biopolymer, University of Tabriz, Tabriz, Iran

*Corresponding author:

Dr Mehdi Shafiee Ardestani

Assistant Professor

Hepatitis and AIDS Department, Pasteur Institute of Iran

Department of Medicinal and Radiopharmaceutical Chemistry, Tehran University of Medical Sciences

Tehran, Iran

Tel/Fax: +9866953311

Email: shafieeardestani@gmail.com

$\underline{\Delta}$ This paper is a thesis submitted for M. Sc. Degree in Biochemistry by Mrs. Saba Zakery.

\begin{tabular}{l|l|l} 
Received: 24 March 2012; & Revised: 5 April 2012; & Accepted: 7 May 2012
\end{tabular}

\begin{abstract}
Wilson's disease (WD) is an autosomal recessive disorder in which copper metabolism is impaired. In fact, copper accumulates in various organs and tissues can be seen and causes toxic effects in various tissues including liver, brain, kidneys and eyes. Sulfur amino acid is a metabolite of D-penicillamine and penicillamine and copper Chlator is a factor that causes urinary excretion of copper and WD therapeutic agent as well. The interesting thing about the neurological symptoms of Wilson's disease with penicillamine is the drug may worsen or even in an asymptomatic patient, the treatment may be creating symptoms. DTPA is a pentavalent compound containing carboxylic DTPA is a chemical compound that is used in radiation therapy and MRI. It can give the metal chelate with iron, copper and other cations can be conjugated and also treatment of internal body pollution caused by various elements, including raDOIactive elements. DTPA could not be lonely absorbed by the cell. The goal is to conjugate it with the G2 Dendrimer (Nanosized anionic linear biocompatible polymer) to bring it to the nano size and increase the intracellular uptake compared to the ground state. Based on the hypothesis, nanoconjugated DTPA-Dendrimer G2 was synthesized and then evaluated on Hep G2 WD cell model in vitro and the results showed a good effectiveness without any toxicity for the conjugate in decreasing the intracellular copper level comparing to gold standard D-penicillamine respectively. Based on the findings the nanosized conjugate seems to have very good prognoses and clinical future and this needs to be further investigated.
\end{abstract}


Keywords: Wilson's disease (WD), nanosized conjugate, DTPA, Anionic linear globular Dendrimer, HepG2.

\section{Introduction}

Wilson's disease (WD) is a disease in which the analysis of copper metabolism is impaired $(1,2)$. On the other hand, the disease is an autosomal recessive disorder of copper metabolism which causes to copper accumulation in various organs and tissues that can be seen as clinical features. Toxic copper accumulation in various tissues such as liver, brain, kidneys and eyes are reported first time in 1912 by Kinner Wilson as a degenerative disorder of neurological symptoms and these were associated with cirrhosis, In 1912, Hall reported symptoms of liver disease and degeneration and called Hepatolentycolar $(3,4)$ Further studies revealed that the disease is more common in families of patients (5). Hall showed that the disease is commonly more observed in children whose parents have WD $(6,7)$.

In 1956, Walshe successful use of oral Dpenicillamine as a copper reducing agent in the WD treatment reported $(8,9)$. Penicillamine is a penicillin metabolite of sulfur amino acids and is a factor in the copper Chlate formation that causes to urinary excretion of copper, which is the primary act of D-penicillamine, so free and toxic copper will be out of the reach of hepatocytes and thus reduces the cell damage (10).

The interesting thing about the neurological symptoms of WD with penicillamine is the drug may worsen or even caused to increase in an asymptomatic disorder and as a result, this treatment may be the cause of symptoms $(10,11)$. To improve D-penicillamine side effects and as an alternative treatment trientine was designed and approved to use clinically in those with severe drug reactions with D-penicillamine and it is preferred as first-line treatment in patients with neurologic symptoms. But many of the side effects seen with D-penicillamine is also seen in trientine therapy especially in women and hence, there is a need for generation of novel safe and effective anti-WD agents $(12,13)$.
In biomedical application such as drug delivery or medical imaging, size plays a significant role in the efficacy and success of the treatment. Macro size has notable draw-backs when compared to nano-size with regard to biological applications, due to the size of cellular and subcellular compartments. For instance, conventional micron-size drug delivery techniques in cancer therapy suffer from inefficacy of delivery, inadequate targeting, toxic effects on healthy tissues, and impaired transport to tumor sites $(14,15,16)$.

However, micron sized $(\mu \mathrm{m})$ cell entering vehicles cannot traverse in a passive fashion through cells and cell pores, and this also includes tumor cells with pore sizes as big as $380-780 \mathrm{~nm}$. As a result, the ideal system for biological applications would be a targeted nano-delivery system (14-18).

Increasing the drug bioavailability at its action site (e.g., extracellular or even intracellular) may cause to increase the drug potency and or to reduce the administered dose therefore, to decrease the drug toxicity $(19,20)$. This is often possible by means of safe nanocarriers $(21,22)$ such as anionic linear globular dendrimers (2325). Dendrimers are macromolecules which contains generally from three full branches. (26, 27). Today, polymeric structures with very low poly dispersity, eg, dendrimers, are being preferred as carriers of drugs. Dendrimers are a series of polymeric architectures with different chemical and surface-related properties. A large number of superiorities over traditional polymers have been proclaimed for these dendritic structures such as nanoscale (nanometer-sized polymers) architecture, narrow poly dispersity index, and multiple reactive functional sites with the potentiality for bond formation with chemical therapeutics at their surfaces which make them best in this regard $(28,29)$.

Yet, not all of the dendrimers are suitable in this respect; biocompatible properties like water solubility, biodegradation, non-cytotoxicity, nonimmunogenicity features must be verified for them 
in vitro and in vivo. In this report, one generations of a highly water soluble anionic linear-globular dendrimer G2 (MW 2000 Da), poly (ethylene glycol) as the core and citric acid at the periphery, was selected for the subsequent coupling. The dendrimer had been synthesized before showing good efficacy and less toxicity $(30,31,32)$.

Diethylenetriaminepenta acetic acid (DTPA) is very strong chemical that is classified in categories Extra Cellular Fluids Contrast Agent (ECFCA) $(33,34)$. Compound has a capacity of 5 carboxylic acid and can give the metal chelate (e.g., iron, copper and other cations). DTPA helps to prevent heavy metal sediment and is used in treating such conditions plus raDOIpharmaceutical aspects $(35,36)$. It should be finally stated that DTPA does not have the ability to cell entrance, but it has a very good copper complex formation. In brief, one of the major concerns in WD therpay is regarding the intracellular copper overload in various tissues specifically hepatocellular tissue and this causes severe toxicities. It should be notified that current anti-WD medications show many side effects and even less intracellular anticopper activities (3-12). Hence, there is a need to investigate the new class of drugs to treat the disease with more safety/ efficacy as well as less cost. DTPA is a low cost and very good metal chelator but it could not able to cell penetrate. (30, 37-38).

The aim of the present study is to conjugate DTPA with the nano-sized anionic linear globular biocompatible dendrimer to generate a novel safe and very powerful intracellular copper overload showing more liabilities comparing to traditionally used drug D-penicillamine.

\section{Materials and Methods}

\section{2-1. Materials}

All chemicals (e.g., DTPA, EDC, ADH...) and all cell experiment's materials (cell culture medium, plates, MTT salt...) were purchased from Sigma-Aldrich Co. (USA) without further biochemical evaluations. All solvents (e.g., Methanol, Chloroform, Diethyl ether...) were also purchased from Merck Co. (Germany). Dialysis bag (500Da cut off) was purchased from Spectrumlabs (Spectra/por ${ }^{\mathrm{R}}$, Rancho Dominguez,
CA, USA) and Sephadex G-25 fine ${ }^{\circledR}$ was also purchased from Merck Co. (Germany). Hep $\mathrm{G}_{2}$ cell lines were provided by the National Cell Bank of Iran, Pasteur Institute of Iran. The FT-IR spectra were recorded on a Nicolet 550 instrument (USA). Silica gel 60 F254 precoated plates (Merck) were used for TLC. The purity of the synthesized compounds was confirmed by thinlayer chromatography (TLC) using various solvents of different polarities. Flame atomic absorption spectrophotometer (PERKIN ELMER) was used for the analysis of $\mathrm{Cu}^{+2}$ ions in aqueous solution. Size and zeta potential distribution change were determined by DLS method (Malvern, Zetasizer Nano ZS, Worcestershire, UK).

\section{2-2. Synthesis}

Based on our previously published data (3039) anionic linear globular dendrimerG2 was synthesized and purified. Following previous step (synthesis of dendrimer), dendrimer was conjugated to adipic acid dihydrizide (ADH, which acts as a linker spacer) to facilate its conjugation to DTPA (1mmole dendrimer: 10 mmole ADH) in the presence of 10 mmole water soluable ethyl dimethyl propylamine carbodiimide EDC and conjugation enhancer / water resistant agent N-Sulfo-Succinamide (N-Sulfo-HS, 5 mmole). To avoid the use of organic solvents $\mathrm{N}$ sulfo-HS was employed to resist water reversing effects on conjugation and to perform the experiment in biological solvents and to make reaction type from conventional to green chemistry. After fictionalization and purification of dendrimer (reaction time $1 \mathrm{hr}$ ) using dialysis bag (cut off 500-1000Da, Spectrum ${ }^{\circledR}$ ), 10 mmole DTPA in water was added dropwise to the solution containing functionalized dendrimer at the presence of 10 mmole EDC again and the reaction mixture was stirred at room temperature for at least one day. Reaction times, purity and impurity of synthesized compounds were monitored by Thin Layer Chromatography TLC.

\section{2-3. Purification}

Gel chromatography is an easy way to separate the mixture of materials based on their molecular size and shapes. The stationary phase is 
composed of Sephadex G25 fine ${ }^{\circledR}$. In fact, a soluble neutral polymer matrix network is formed. The stationary phase usually is saturated by a solvent used in the synthesis or folding refolding procedure, in case PBS or distilled water (40-46).

Gel chromatography of PBS buffer or water is performable while first, the column to be washed to smooth out the gel and prepare the column ready to use and additional material to be removed from the column. Second, the reaction mixture (2$4 \mathrm{ml}$ ) was added to the column (high $=30 \mathrm{Cm}$, Width $=3 \mathrm{Cm}$ ) and the procedure was followed by washing for several times with the solvent (e.g., water). Every 20 drops (external from the column) was collected and placed in a separate tube and assigned with a number and this has been prolonged since tube number 20 . Then each tube was checked by Thin Layer Chromatography (TLC) to ensure and find the synthesized nanosized conjugate. TLC condition was set as a mixture of $7 \mathrm{ml}$ chloroform and $3 \mathrm{ml}$ methanol and the procedure was performed on Silica gel plates and retention factor of the materials has been obtained and compared with our first observations (synthesis step, Retention Factor (Rf) of DTPA, Dendrimer and conjugated DTPA-Dendrimer was calculated). Tubes containing only nanosized conjugate were chosen for the lyophilization step and our next experiments. The synthesis yield was obtained $63 \%$.

\section{2-4. TEM and Zeta/ Size to determine the combination of size and time Nanoconjoge DTPA - Dendrimer}

The conjugates were also characterized by Transmission Electron Micrograph TEM (JOEL 1230; accelerating voltage, $100 \mathrm{kV}$ ). For TEM sample preparation, one drop of Nanosized conjugate or Dendrimer aqueous suspension was placed on a copper grid and the excess volume was removed. The samples were used after drying at room temperature and finally images were taken.

A distribution spectrum from a scale of 0.6 $\mathrm{nm}$ to 6 microns could be measured $(47,48)$. Each of the dendrimer and nanoconjugate $(0.5 \mathrm{mg} / \mathrm{ml})$ was checked for the size and zeta potential distribution change by DLS method (Malvern,
Zetasizer Nano ZS, Worcestershire, UK) in double distilled water D.D.W.

\section{2-5. Fourier transforms infrared FT-IR studies}

The changes in the spectra of the dendrimer, DTPA and Nanoconjugate were examined by FTIR spectroscopy (Thermo-Nicolet, NEXUS 870, Waltham, MA, USA) before and after the conjugation. The shifts in the some wave numbers of the functional groups in the IR were able to show the surface conjugation and even clarify the involved groups in the conjugation process $(49,50)$.

\section{2-6. HepG 2 cell Culture}

First, the cells were frozen and kept at $-80^{0 \mathrm{C}}$ since there is a need for them. Then containing vial was defreeze and cells were ready to grow, defreeze cells were used for the water bath (51). After defreeze cells, they immediately dropped by Sampler the Falcon will centrifuge (52). Flask should be opened under the hood and in a medium inside the flask to avoid contamination. After centrifugation with rpm $1500 \mathrm{rpm}$ for $5 \mathrm{~min}$, the supernatant fluid was removed to empty cells can be deposited, clear supernatant is removed by sampler. Then, the cells shed into the flask containing the cell culture medium and incubated until the cells could be grown. After incubation, cells were washed several times with PBS and to remove the cells (passage procedure) Trypsine/EDTA solution was used and this procedure was continued every 48-72 hrs since the cell mass was shown the confluences above $75 \%$ $(53,54)$.

\section{2-7. WD cell model}

Hepatocellular Cell Carcinoma HepG2 cells in which previously assigned as WD cell model were completely grown in DMEM with $10 \%$ fetal calf serum (FBS) and $200 \mathrm{U} / \mathrm{ml}$ penicillin $\mathrm{G}$ and streptomycin $200 \mathrm{U} / \mathrm{ml}$. During the passage, cells were washed three times in the media, after a period of 48 hours after the cells were cultured in media $0.5 \mathrm{mmol}$ Cuso 4 was added to the medium to reach WD cell model. ${ }^{44-48}$ Every $10^{6}$ cells were chosen for drug assay experiments and each dose of drug/ nanoconjugate was assessed for at least three times. 


\section{2-8. MTT assay method}

3,4,5 Dimethylthiazol-2-yl 2, 5-diphenyl tetrazolium bromide MTT assay is one the current techniques which is widely used for cell viability measurements. This assay is based on the reduction of MTT to formazan by viable cells (5557 58-59). After the end of the incubation times (24, 48 hrs) with various concentrations of the nanoconjugate, the supernatant of the cells (HepG2) were removed, MTT solution was added to each well of the plates at final concentration of $0.5 \mathrm{mg} / \mathrm{ml}$, and the cells were incubated for an additional 4 hours. Thereafter, the solutions were removed, and the dye was dissolved in $100 \mu \mathrm{l}$ dimethyl sulfoxide; the plates were kept in a dark place for another one hour in order to be ready for spectrophotometric determination. The amount of absorption in each well, that is, the conversion of MTT to formazan by metabolically viable cells, was calculated by an automated microplate reader at $570 \mathrm{~nm}$. The results were divided to the absorption of untreated control culture as a percent of viable cells. (Wells containing only culture media.)

\section{2-9. Drug / Nanocinjugate assay}

To drug potency assay, the synthesized nanoconjugate and D-penicillamine at different doses were prepared and injected on separate plates containing $10^{6}$ cells and the experiments were repeated for at least three times for each dose. It should be stated that negative control containing untreated cells + medium and positive control (WD cell model) were also prepared. After incubation time of $24 \mathrm{hrs}$ drug and cells, the cells have been broken by grinding glass beads in a 50 $\mathrm{ml}$ tube at $100^{\circ \mathrm{C}}$ by a $45 \mathrm{~Hz}$ electric motor for 20 minutes (60-61). The seeds and disrupted cells were removed by centrifugation; Supernatant solution was removed for copper assay with Atomic Absorption spectroscopy.

\section{2-10. The Flame Atomic Absorption Spectrophotometer}

Flame atomic absorption spectrophotometer (PERKIN ELMER ) was used for the analysis of $\mathrm{Cu}^{+2}$ ions in aqueous solution. Concentrations were determined after calibrating the instrument with standards within the concentration range of
5-50 mg/l for $\mathrm{Cu}^{+2}$. Each determination was repeated three times and the results are the average values .To measure the unknown $\mathrm{Cu}$ (II) ions in high concentration, it was diluted with distilled de-ionized water to bring the concentration within the calibration concentration interval .The $\mathrm{pH}$ measurements of all solutions were done with $\mathrm{PH}$ meter And Cell debris were collected by centrifuge model Sigma 3-16PK(Germany) $(60,61)$.

\section{2-11. Nanoconjugate IC50 or EC50 Calculation}

(half maximal effective concentration or half maximal inhibitory concentration)

EC50 refers to half concentration of drug effectiveness or toxicity of a drug which causes to decrease intracellular copper concentration to $50 \%$ of ground state (WD cell model). ${ }^{62,63}$ For this purpose linear model was used to assess nanosized DTPA-dendrimeric conjugateIC50 based on the curve in which dose of drug is $\mathrm{X}$ and $\mathrm{Y}$ is regarding to intracellular copper concentration. Based on the obtained linear equation curve IC50 could be calculated.

\section{2-12. Statistical analysis}

Data interpretations were performed by SPSS 19 software using One way ANOVA with post hoc TUKEY test and the data comparison covering $\mathrm{P}<0.05$ was considered significant. The data presentation is based on Mean \pm SEM or SD (size and zeta potential).

\section{Results}

\section{3-1. Synthesis}

Based on TLC results, the first four tubes showed no presence of a spot regarding any materials. Tube numbers 5 and 6 showed TLC spots with $\mathrm{Rf}=0.76$ represents the DTPA surfaced conjugated dendrimer G2. It should also be stated that DTPA, ADH, EDC, Nsulfo-HS, DendimerG2 and DendrimerG2-ADH)'s Rfs were previously obtained as $0.96,0.43,0.90,0.56,0.94$ and 0.88 respectively. According to gel filtration rules; high molecular weight compound is exit from the column faster than those of having lower molecular weight materials and based on the explained reasons (different $\mathrm{Rf}$ and rapid exist 
from the column) tubes 5 and 6 were identified to contain DTPA-DendrimerG2. (Pattern for chromatographic purification of the reaction mixture were elaborately depicted in Fig.1).
$\mathrm{Rf}=$ distant of solvent on TLC plate/ distant of each spot on TLC plate.

Purification using Sephadex G-25 Fine

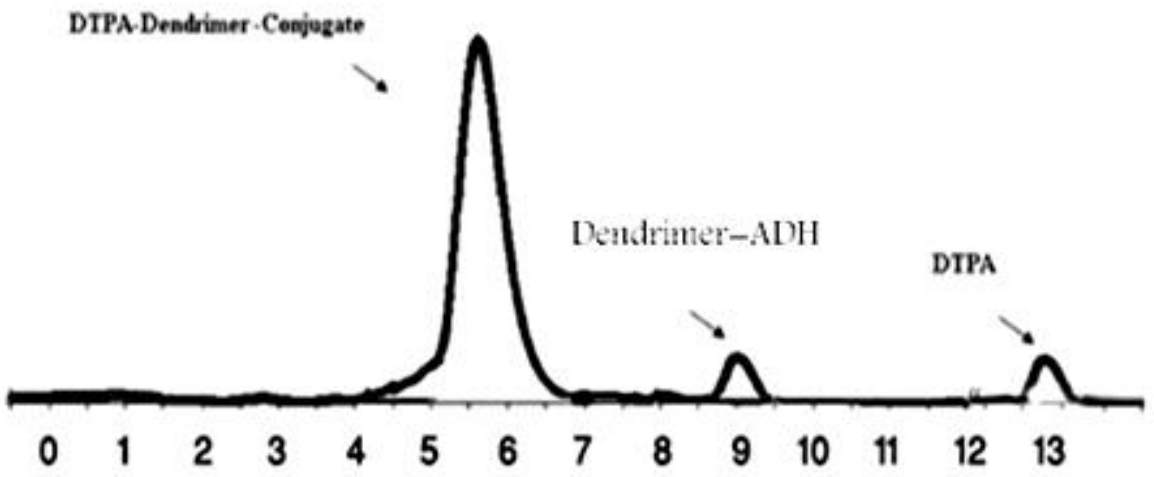

(ml)

Figure 1 Demonstrative purification steps by sephadex G-25 fine system.
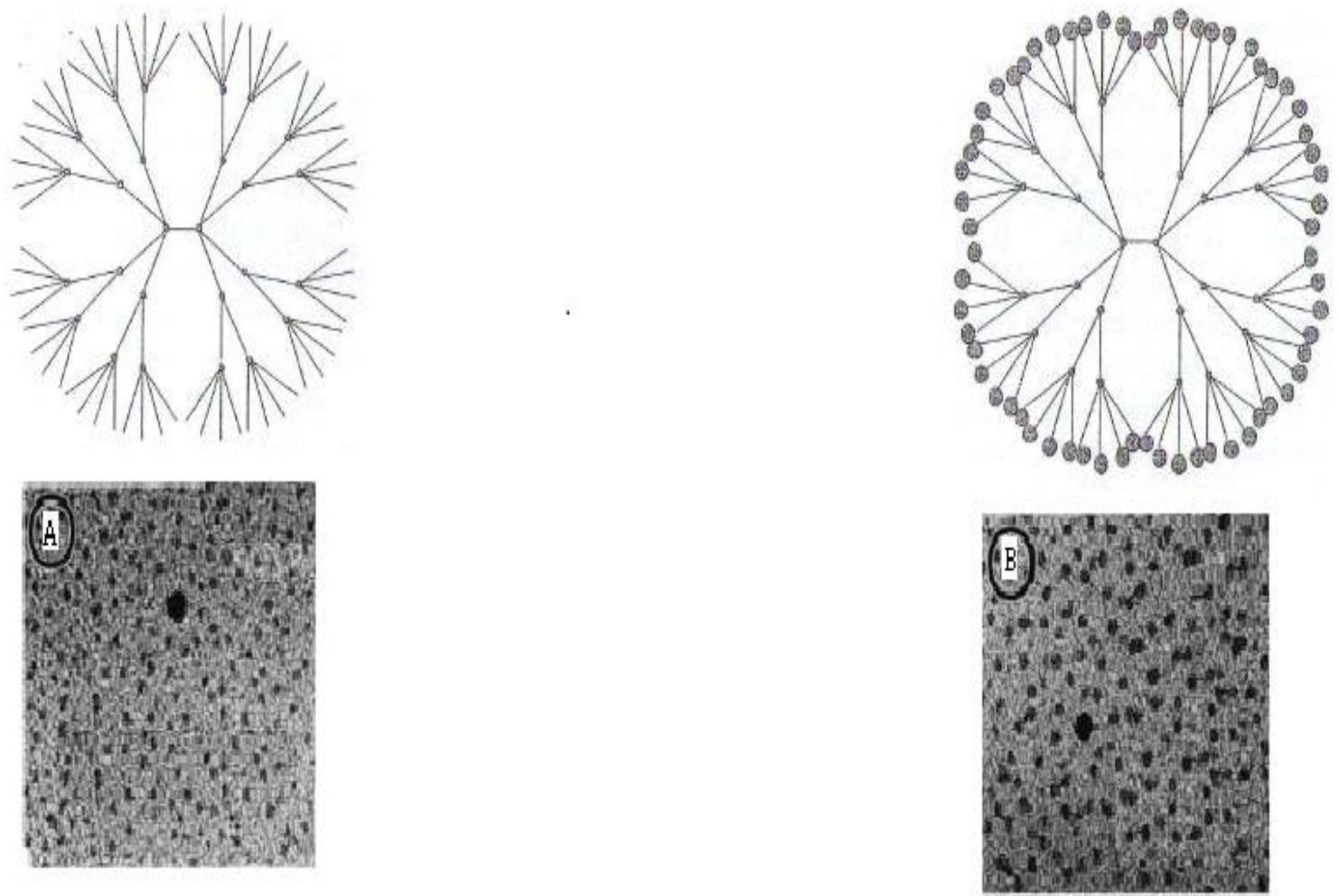

Figure 2 TEM images before and after dendrimer being conjugated with DTPA 

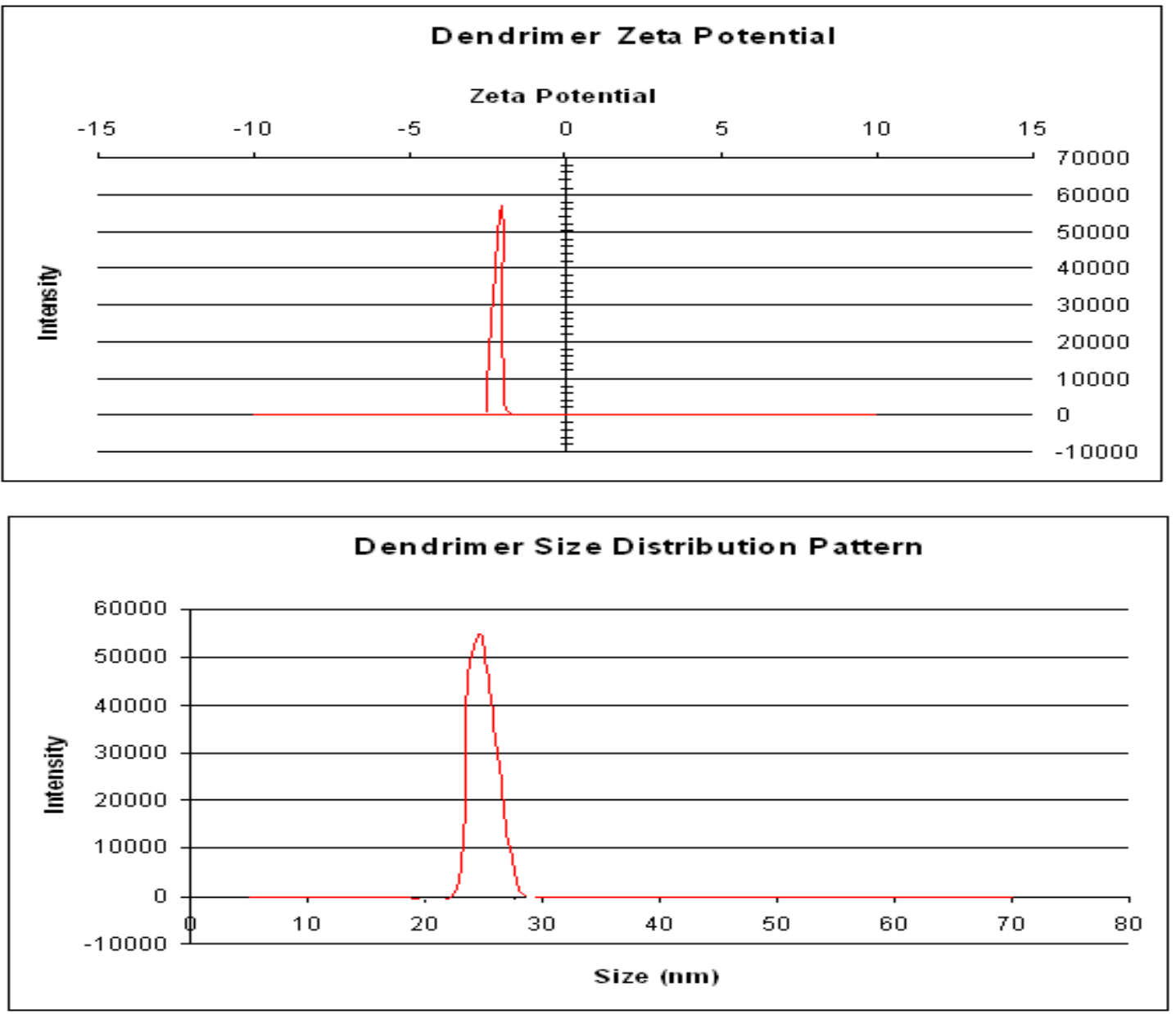

Figure 3 Zeta potential and size distribution pattern of dendrimer G2

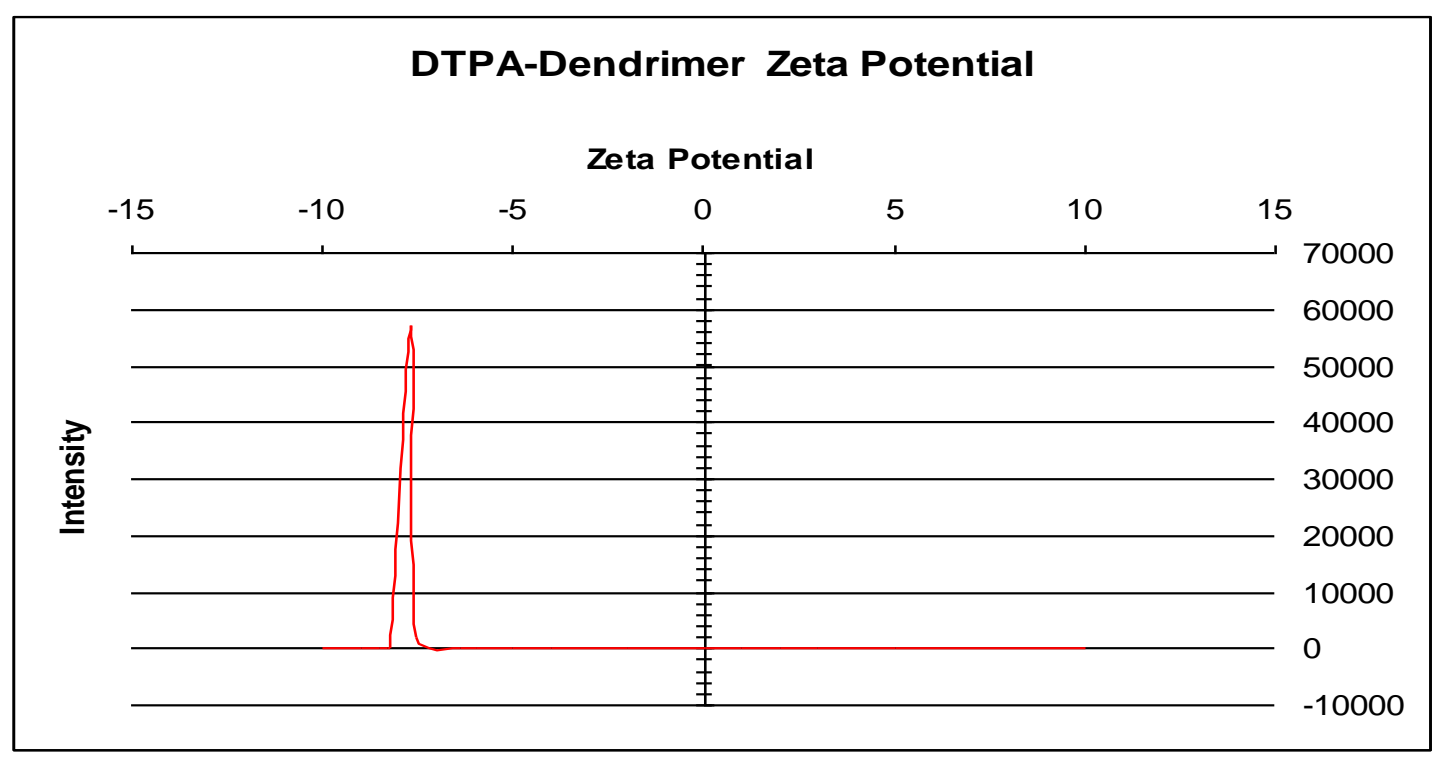

Figure 4 Nanoconjugate DTPA - Dendraimer zeta potential pattern 


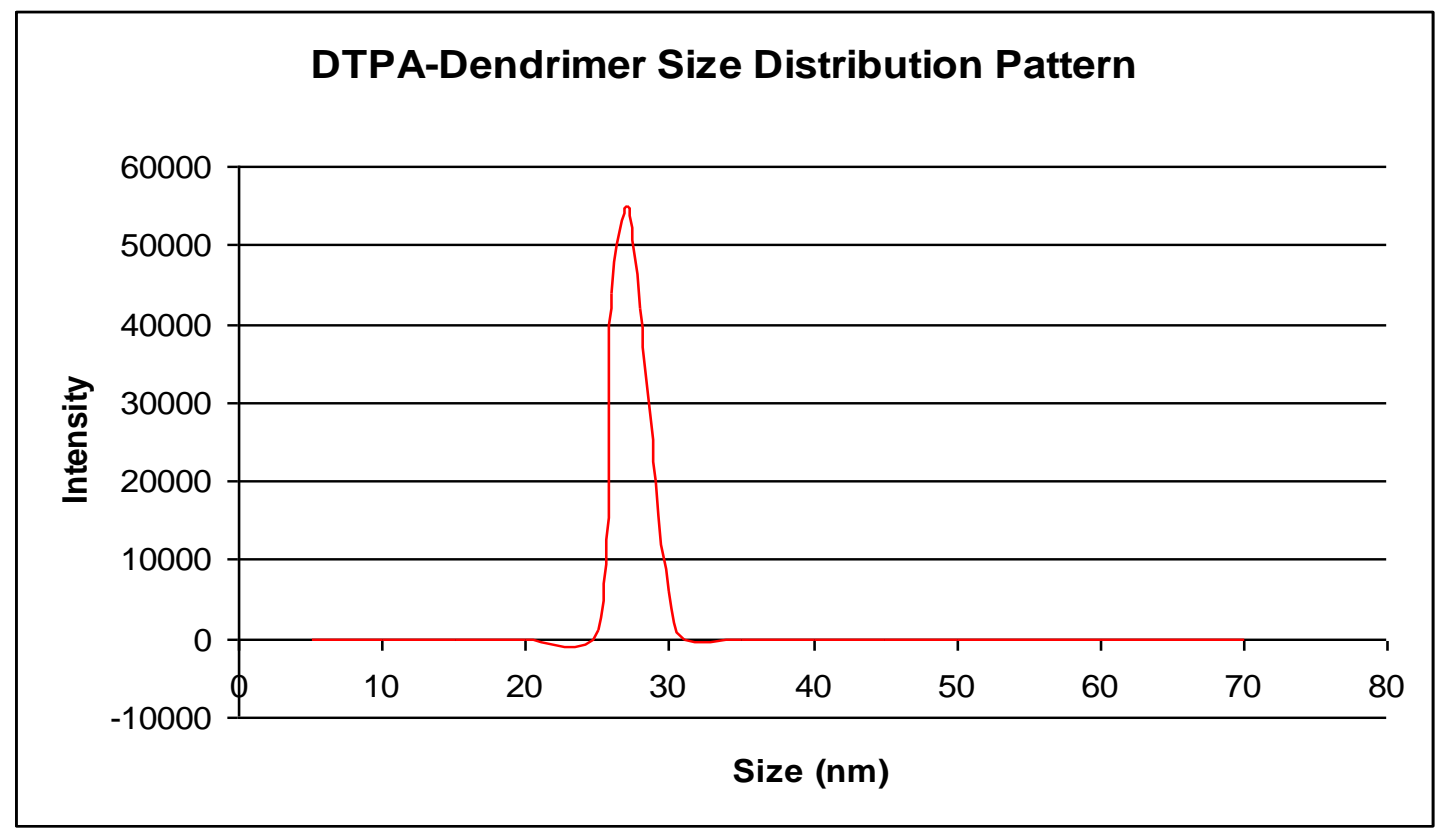

Figure 5 DTPA-Dendrimer Nanoconjugate size distribution

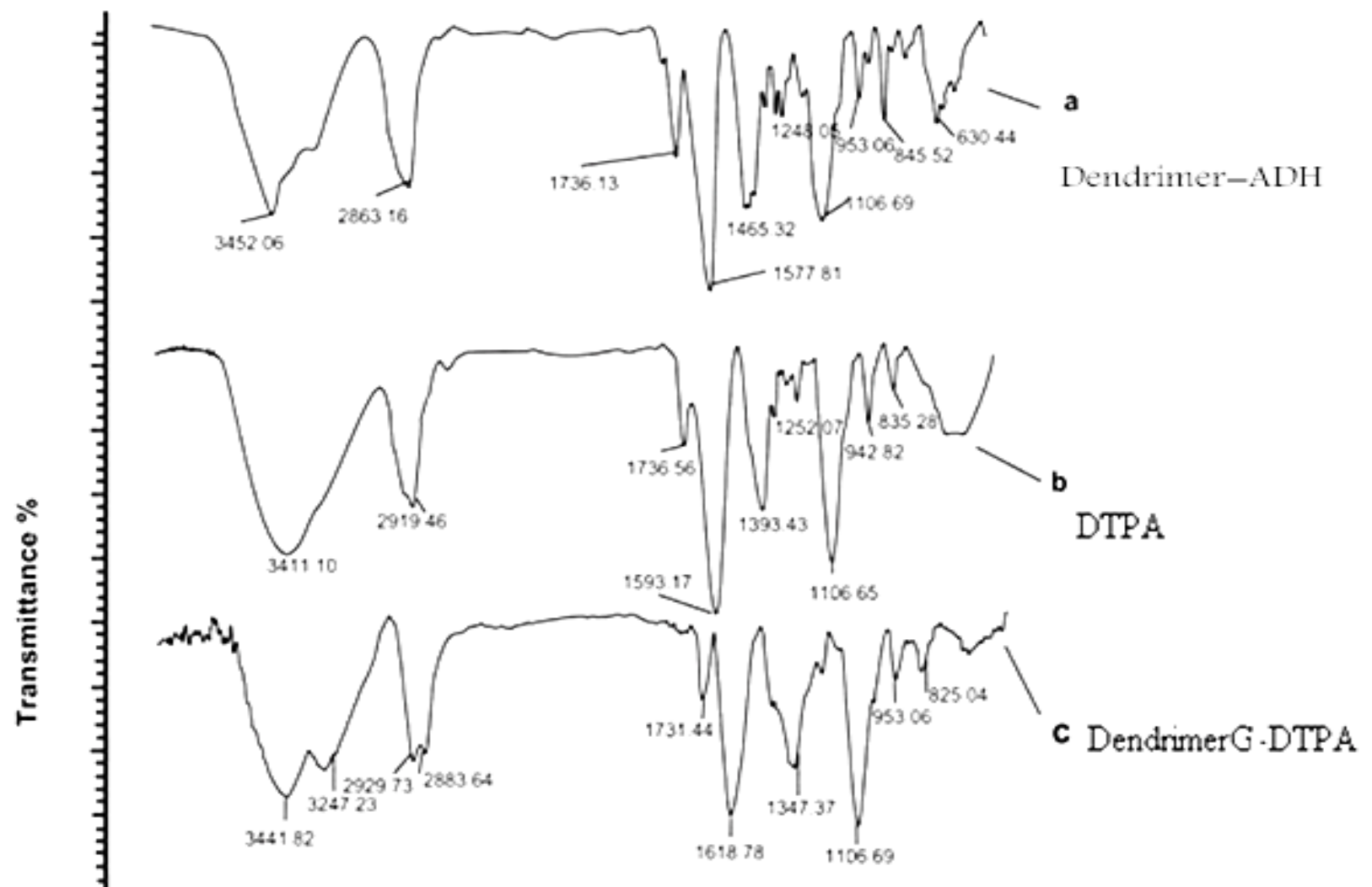

Wavenumber (cm ')

Figure 6 Comparative FT-IR spectrums of DTPA, Dendrimer-ADH and DTPA-Dendrimer. Common peaks and peaks regarding amide conjugation at 1618 and $3247 \mathrm{Cm}^{1-}$ at DTPA-Dendrimer prove the conjugation easily. 


\section{3-2. Electron microscope images and Sizes and times using the $\mathbf{Z}$-Sizer}

TEM images showed a significant increase in the glubolar shape of dendrimerG2 after surface DTPA conjugation (Fig.2). The obtained data showed a significant increase in size and also zeta potentioal of dendrimer after DTPA surface conjugation as well. This phenomenon may refer to increase the carboxylic groups at the dendrimer surface. (Table 1) ( Fig.3, 4, 5)

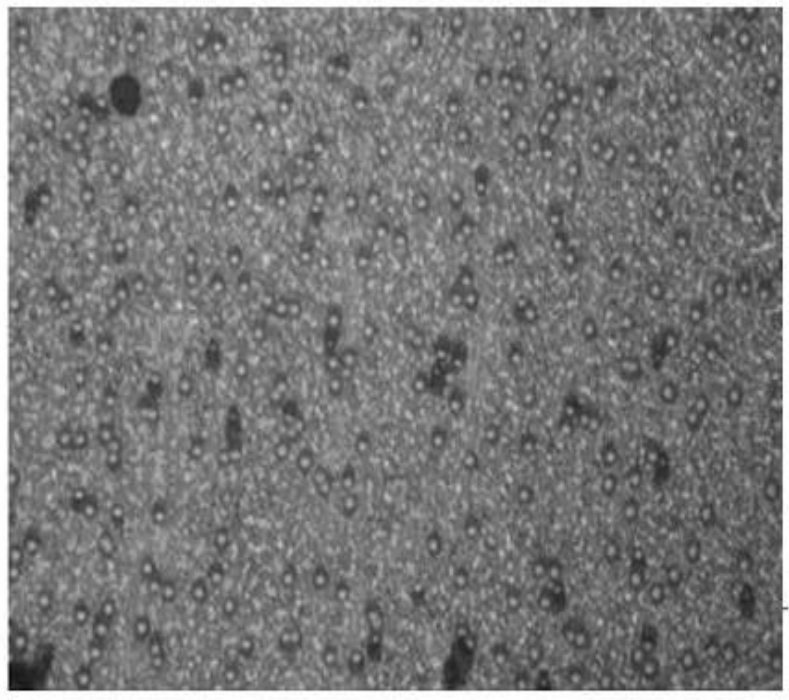

Hep G2 Cells
Table 1: Demonstrative mean \pm SD of size and zeta potential of nanoconjugate and dendrimer.

\begin{tabular}{|c|c|c|}
\hline PARTICLES & $\begin{array}{c}\text { DIAMETER } \pm \\
\text { SD }(\mathrm{nm})\end{array}$ & $\begin{array}{l}\text { POTENTIAL } \pm \\
\text { SD }(\mathrm{mV})\end{array}$ \\
\hline DTPA & $\begin{array}{l}\text { DTPA is a small molecule and zetasizer } \\
\text { could not able to show its size. DTPA } \\
\text { Size }<0.6 \mathrm{~nm}\end{array}$ \\
\hline Dendrimer & $25 \pm 4$ & $-2.11 \pm 0.12$ \\
\hline DTPA Dendrimer & $28 \pm 5$ & $-7.53 \pm 0.53$ \\
\hline
\end{tabular}

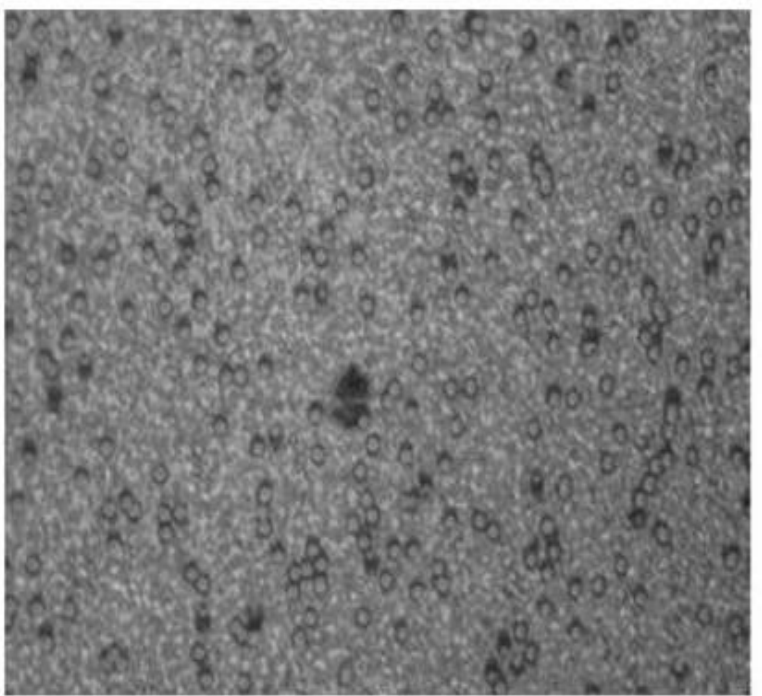

Hep G2 Cells after 24 treatment with Dend-DTPA

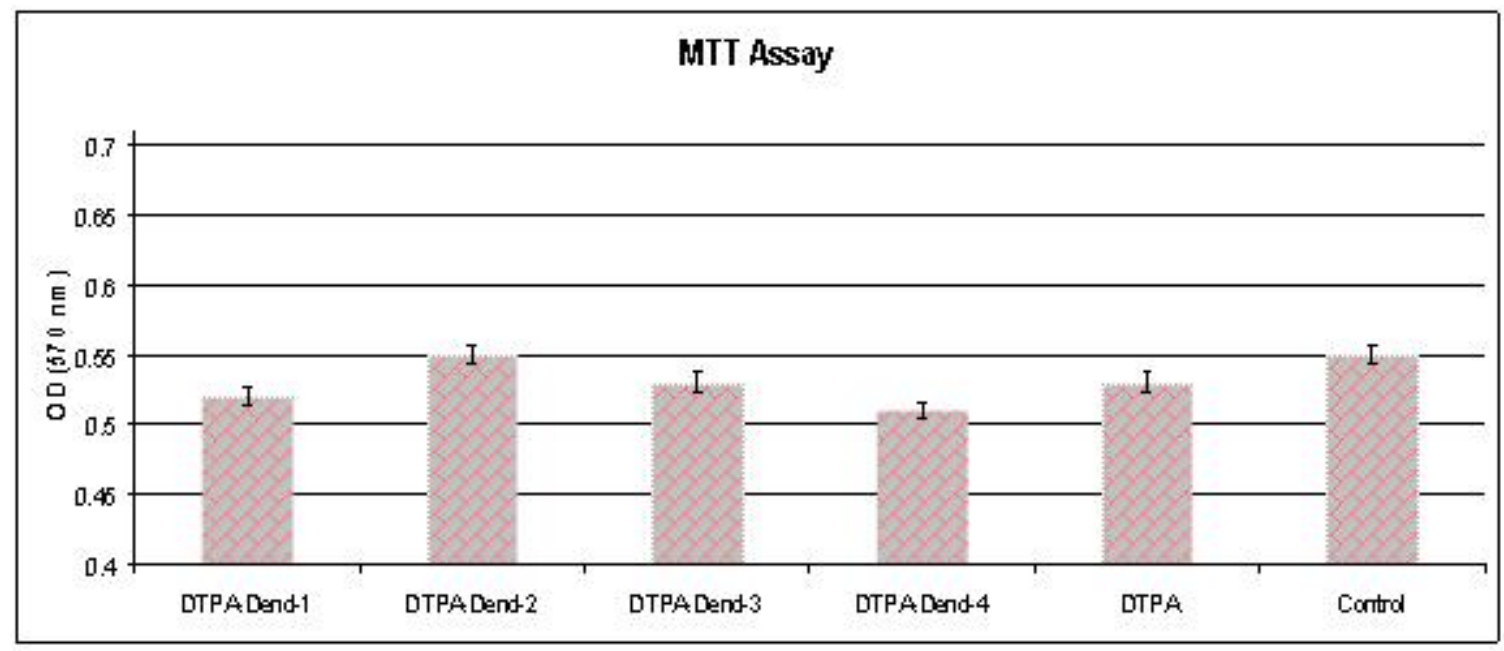

Figure7: Optical microscope images and MTT results before and after nano-scaled DTPA exposure to HepG2 cells. No toxic effect was observed. (DTPA-DendrimerG2 conjugate different doses were assigned as numbers 1, 2, 3, 4 which equals to 50,100, 150 and $200 \mu \mathrm{g} / \mathrm{ml}$ respectively, DTPA concentration was $200 \mu \mathrm{g} / \mathrm{ml}$ ) 


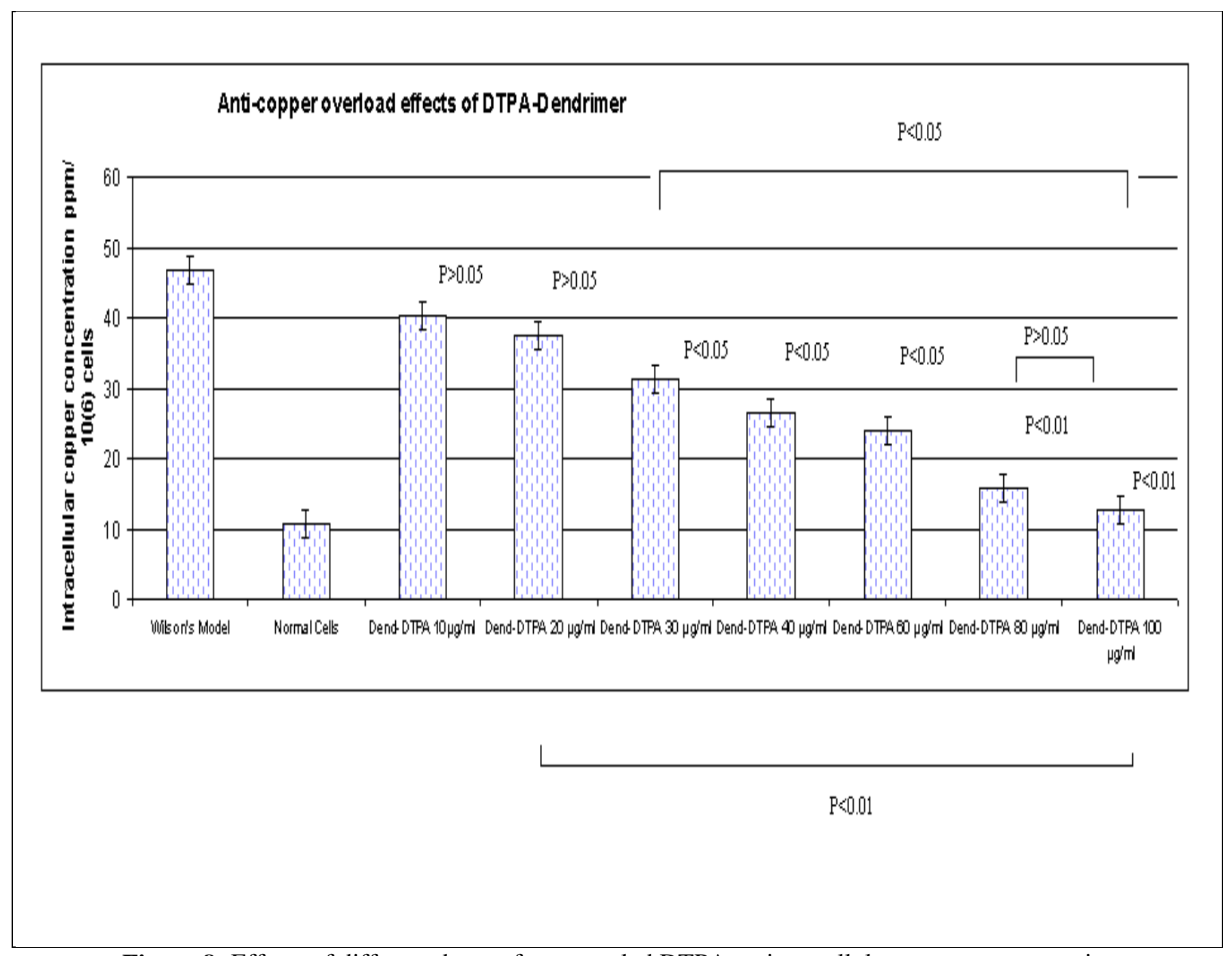

Figure 8: Effects of different doses of nano-scaled DTPA on intercellular copper concentration.

\section{3-3. FTIR data interpretation}

Below mentioned peaks at the spectrum of nanosized conjugate is confirming the conjugation:

1- Being seen as a clear peak at $1700-1800 \mathrm{~cm}$ reverse (-COOH or carbonyl)

2- Being seen as a clear peak at $1600-1700 \mathrm{~cm}$ reverse (NH- amide)

3- Being seen as a clear peak at $3000-3500 \mathrm{~cm}$ reverse $(\mathrm{OH}$ or $\mathrm{NH})$

Besides of the above the common peaks between Dendrtimer and DTPA were also easily find at DTPA-DendrimerG2 spectrum.(Fig.6)

\section{3-4. Cellular Toxicity Assay (MTT assay results)}

As it can be seen in Fig.7 nanosized anionic linear globular dendrimer G2-DTPA conjugate caused to not any significant alteration in viable
HepG2 cell numbers at all. On the other hand, no toxic effect $(\mathrm{P}>0.05)$ was observed. It should be additionally stated that dendrimer G2 previously assessed and showed no significant toxic effects as well (30). This observation showed that dendrimer-DTPA surface conjugation did not produce any significant cell toxicity.

\section{3-5. Nanoscaled DTPA effect on intracellular copper concentration}

As it can be seen in Fig.8 DTPA-Dendrimer with different doses from $10-100 \mu \mathrm{g} / \mathrm{ml}$ has been administered on WD cell models and this compound caused to significant $(\mathrm{P}<0.05)$ decrease in intracellular copper concentration from WD cell model state to near normal cells content except 10 and $20 \mu \mathrm{g} / \mathrm{ml}$ which showed no significant effects. In overall view as elaborately demonstrated in Fig.9 alone DTPA had not shown any significant 
alteration in copper concentration and it is probably due to DTPA negative charges which cause to prevent cell penetrate. In contrast dendrimer G2 because of its nanosize structure may penetrate to the cell and due to its polycitric acid structure may form copper complex and as result showed a very good potency to decrease copper concentration but less than the nanosized DTPA-dendrimer conjugate. Nanoscaled DTPA at doses 80 and $100 \mu \mathrm{g} / \mathrm{ml}$ showed a more significant $\mathrm{P}<0.05$ effects on lowering the intracellular copper concentration than other concentrations of DTPA, Dendrimer or even 10-60 $\mu \mathrm{g} / \mathrm{ml}$ dendrimer-DTPA doses.

\section{3-6. Nanoscaled DTPA and D-penicillamine Comparative study}

As it has been shown in Fig. 10, administration of standard drug D-penicillamine with high doses $500-1000 \mu \mathrm{g} / \mathrm{ml}$ caused to significant decrease in copper concentration comparing to controls but its liability was observed significantly $\mathrm{P}<0.05$ less than DTPADendrimer or even alone DendrimerG2 at dose of $500 \mu \mathrm{g} / \mathrm{ml}$. The comparative study showed an equal potential for both doses of $100 \mu \mathrm{g} / \mathrm{ml}$ of nanoscaled DTPA and $1000 \mu \mathrm{g} / \mathrm{ml}$ of standard drug D-penicillamine. The interesting finding is the comparative ratio of nanoscaled DTPA to Dpenicillamine which obtained 1:10. On the other hand, nanoscaled DTPA showed an equal or even more effects on decrease the intracellular copper concentration with 0.1 dose of D-penicillamine without showing any cellular toxicity.

\section{3-7. EC50 Calculation}

Based on the DTPA-DendrimeG2 doses $\mathrm{X}$ and the Reponses to the drug $\mathrm{Y}$ (copper concentration) EC50 curve was depicted and linear model was obtained. ( Fig.11) Based on the below calculations NanoconjugateDTPADendrimerG2EC50 has been performed:

Linear model equation: $y=-0 / 6467 x+90 / 516$

If $\mathrm{y}=50 . \mathrm{x}=\mathrm{EC} 50$

$50=-0.6467 x+90.516$

$-40.516=-0.6467 \mathrm{x} \quad \mathrm{X}=\mathrm{EC} 50=62.6 \mu \mathrm{g} / \mathrm{ml}$ $62.6 \mu \mathrm{g} / \mathrm{ml}$ is apparently much less that $\mathrm{D}$ penicillamine EC50 and based on its safety and powerful effects it can propound as new WD alternative therapy in near future.

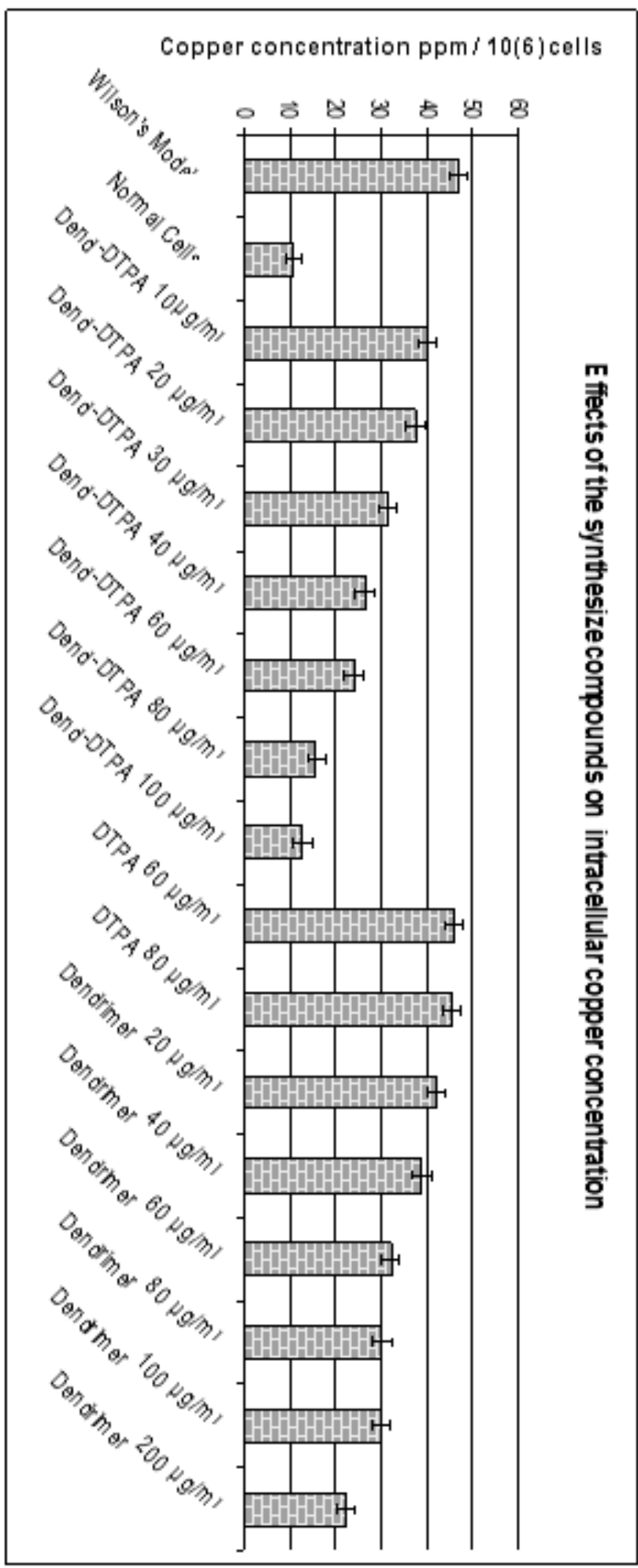

Figure 9 Overview comparing effect of all materials used in this study 

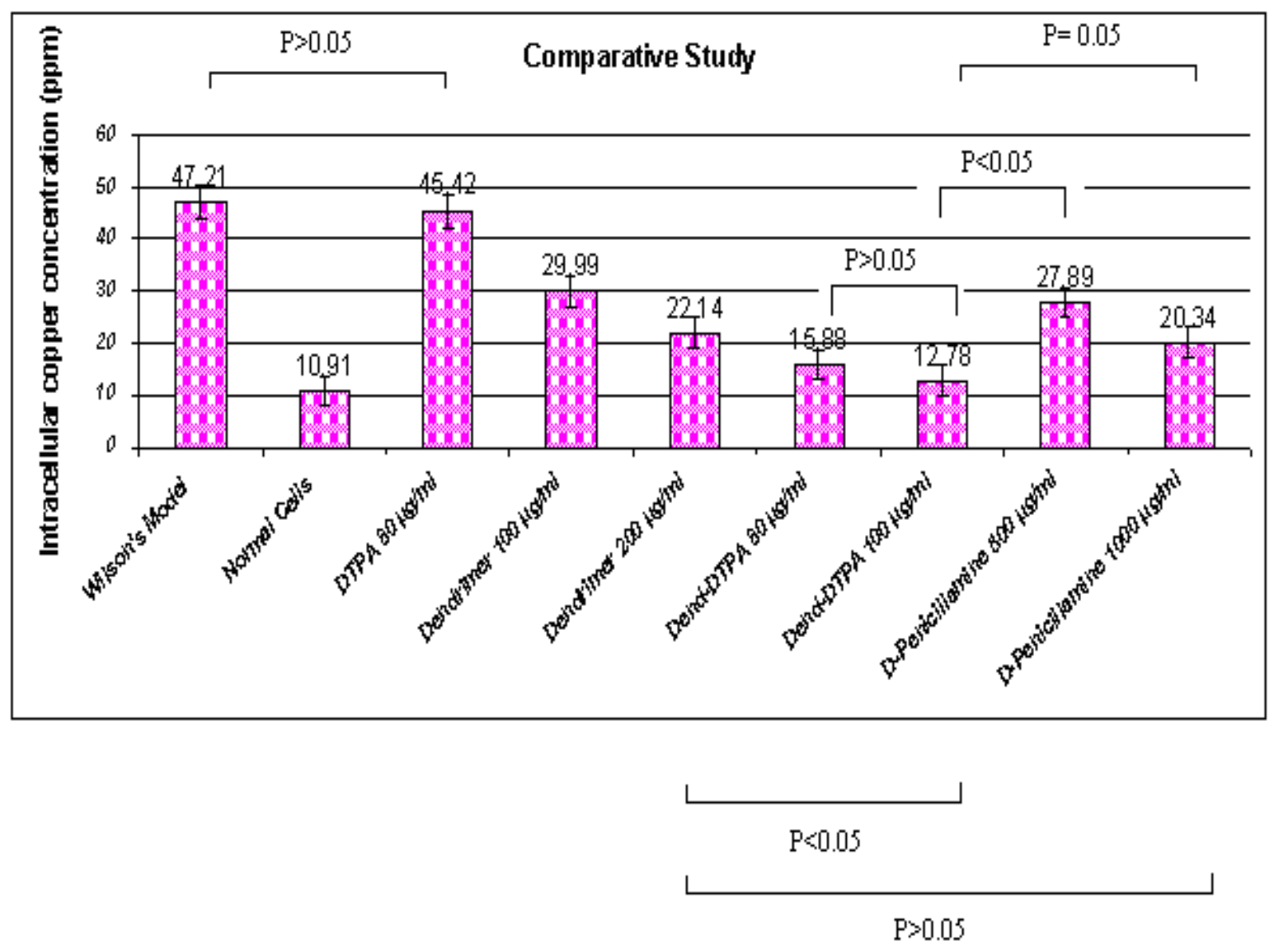

Figure 10: Illustration of the high dose comparative effects of Nano-scale of DTPA with D-penicillamine, DTPA and DendrimerG2

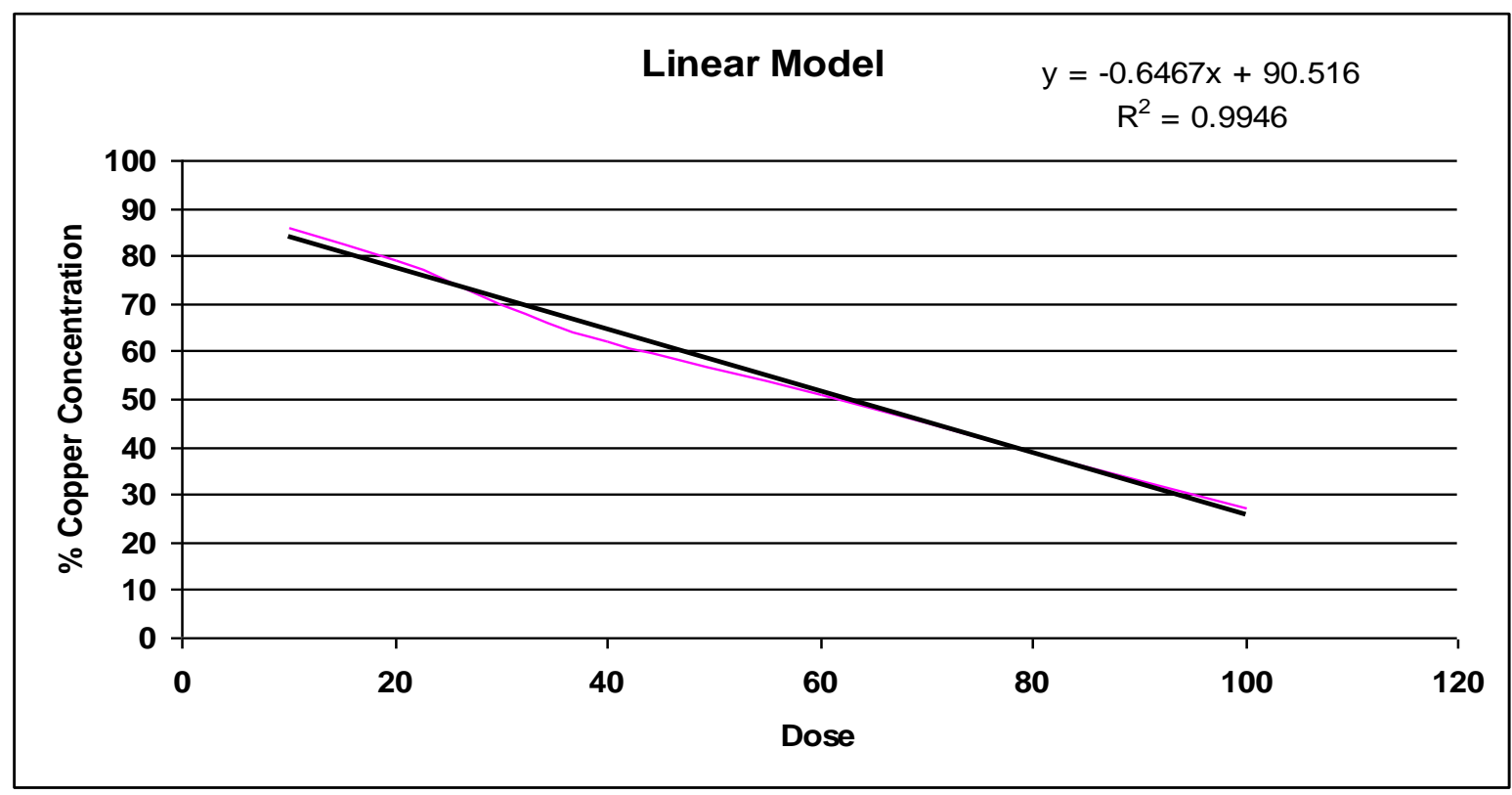

Figure 11: EC50 demonstrative cure which is the drug dose curve that determines the 50\% potency in reduction of copper is deposited for the generated nanoscale of DTPA. (Colored line is the obtained original data curve and black line is the excel calculated curve which is completely correlated with the original data) 


\section{Discussion}

First discovery regarding the present study is to generate novel nanoscale of DTPA. It is well established that DTPA as metal chelating agent could not able to enter the cells but generating nanoscale of DTPA based on anionic linear globular biocompatible dendrimerG2 conjugation is well shown a significant cell penetration because of the significant decrease in intercellular copper concentration. Second interesting finding regarding the present data is to decrease toxicity comparing the current anti-WD agents. On the other hand, our generated DTPA nanoscale showed a very potent anti-WD effect without any cell toxicity. Third finding is about cost benefit of generated nanoscale of DTPA because the conjugate is composed from low cost materials DTPA and polycitric acid backbone dendrimer. Anionic charges of both dendrimer and DTPAdendrimer is a major cause of lowering the toxic effects, because negative charge at cell surface can far our conjugate negative charge a way and thus it may cause to avoid any surface-surface interactions and subsequent toxicity $(64,65)$. This phenomenon may be also regarded to polycitric acid structure and also anionic charge of its surface which produces a biocompatible nanocarrier. It is additionally added that dendrimer G2 cell uptake mechanism is regarding to receptor mediated endocytosis ${ }^{30}$ and its negative charge did not interfere with cell uptake at all and just decrease the toxicity.

Today, Various treatments but with some insufficiencies are available for WD. Some increase the removal of copper from the body, while others prevent the absorption of copper from the diet.

Generally, penicillamine is the first treatment used. This binds copper (chelation) and leads to excretion of copper in the urine. Hence, monitoring of the amount of copper in the urine can be done to ensure a sufficiently high dose is taken. Penicillamine is not without problems: about $20 \%$ experience a side effect or complication of penicillamine treatment, such as drug-induced lupus (causing joint pains and a skin rash) or myasthenia (a nerve condition leading to muscle weakness). In those who presented with neurological symptoms, almost half experience a paradoxical worsening in their symptoms. While this phenomenon is also observed in other treatments for Wilson's, it is usually taken as an indication for discontinuing penicillamine and commencing second-line treatment (1-17). Intolerant to penicillamine may instead be commenced on trientine hydrochloride, which also has chelating properties. Some recommend trientine as first-line treatment, but experience with penicillamine is more extensive (7-12). A further agent with known activity in Wilson's disease is tetrathiomolybdate. This is still regarded as experimental, (7) although some studies have shown a beneficial effect (1, 6-18). Based on the above, our discovered agent seems to be a better compound because of advantages as follows: a) Its production is cost benefit b: Having not any significant cellular toxicity c: Good therapeutic potency and d: Low IC50 $62 \mu \mathrm{g} / \mathrm{ml}$ (Nanoscaled DTPA to D-penicillamine ratio; $1: 10$ ).

It should be finally added that further in vitro and in vivo animal model investigations are necessary to find underlying mechanisms of nanosized DTPA action and or subsequent clinical experiments are needed to prove the nanoscale derivative of DTPA liability as a novel WD alternative therapeutic agent.

\section{Acknowledgments}

Tehran University of Medical Sciences and Pasteur Institute of Iran supported this study. The authors are grateful to thank all technicians who provided support during the course of research. This research is proudly dedicated in living memory of Dr. Mohammad Izaddoost.

\section{References}

1. Frydman M. Genetic aspectsof Wilson's disease. J GastroenterolHepatol (1990); 5:48390

2. Hassan WN, Mohamed MS, Ahmed EH et al. Tumor Necrosis Factor- $\alpha$ and Iron Overload Are Associated with Insulin Resistance in Hepatitis $\mathrm{C}$ in Egyptian Patients. Am. J. 
Biomed. Sci. 2010, 2(4), 342-351, DOI: $\underline{10.5099 / a j 100400342}$

3. Carpenter TO. Hypoparathyroidismin Wilson'sdisease. N Engl J Med. 309, 873-877 (1983).

4. Klee JG. UndiagnosedWilson's disease as causeof unexplained miscarriage. Lancet. 2, 423 (1979).

5. Bull PC. The Wilsondisease gene is a putative coppertransporting P-type ATPase similar to the Menkes gene. Nat Genet. 5,327-37 (1993).

6. Tanzi RE. The Wilsondisease gene is a coppertransporting ATPase with homology to the Menkes diseasegene. Nat Genet . 5, 344350 (1993).

7. Yamaguchi Y. Isolationand characterization of a humanliver cDNA as a candidate gene for Wilson disease. BiochemBiophys Res Commun. 197, 271-27(1993), DOI: 10.1002/ hep. 1840200235

8. Czlonkowska A. Effectsof long term treatment in Wilson's disease with D-penicillamineand zinc sulphate. J Neurol. 243, 269-267 (1996). DOI: $10.1007 / \mathrm{BF} 00868525$

9. Scheinberg IH, SternliebI. Wilson's disease. In: SmithLH Jr., Ed. Major Problems in Internal Medicine. Philadelphia:W.B. Saunders Company,23 (1984). DOI: 10.1002/ hep. 1840040706

10. Hilla VA. Penicillamine-induced elastosis perforans serpiginosa and cutis laxa in Wilson's disease. Br J Dermatol. 142, 560-561 (2000). DOI: $10.1046 / \mathrm{j} .1365-$ 2133.2000 .03379 .

11. Brewer GJ. Worseningof neurologic syndrome in patients with Wilson's disease with initial penicillaminetherapy. Arch Neurol. 44, 490493 (1987).

12. Scheinberg IH. Theuse of trientine in preventing the effects of interrupting penicillamine therapy in Wilson's disease. $\mathrm{N}$ Engl J Med. 317, 209-213(1987).

13. Walshe JM. Treatment of Wilson's disease with trientine (triethylene tetramine) dichloride. Lancet. 1,643-647 (1982).

14. Brewer GJ. Neurologically presenting Wilson's disease: epidemiology, pathophysiology and treatment. CNS Drugs. 19, 185-192 (2005).
15. Lakkireddy JS, Adhikari BSR, Dwarkanath ,et al, Tumoricidal effects of etoposide incorporated into solid lipid nanoparticles after intraperitoneal administration in Daltons lymphoma bearing mice. AAPS J. 8,2: article N. 29 (2006). DOI: 10.1208/aapsj080229

16. Maiaa CS, Mehnertb W, Schallerc M, et al. Drug targeting by solid lipid nanoparticles for dermal use. Journal of Drug Targeting. 10,489-495 (2002) DOI:10.1080/ 1061186021000038364

17. Shaffer C. Nanomedicine transforms drug delivery. Drug Discov Today. 10,1581- 1582 (2005). Papazoglou E.S, \& Parthasarathy A. Bionanotechnology. Morgan \& Claypool;,4-20 (2010).

18. Schwarz C, Mehnert W, Lucks JS, Muller RH. Solid lipid nanoparticles for controlled drug delivery, J Control Rel. 30, 83-96 (1994). Doi./10.1016/0168-3659(94)90047-7

19. Moghimi SM, Hunter AC, Murray JC. Nanomedicine: current status and future prospects. FASEB J 19, 311 - 330 (2005). Doi: 10.1096/fj.04-2747

20. Jenning V, Lippacher A, Gohla SH. Medium scale production of solid lipid nanoparticles (SLN) by high pressure homogenization. J. Microencapsul. 19,1-10 (2002)

Doi: $10.1080 / 713817583$

21. Lee KE, Cho SH, Lee HB, Jeong SY, Yuk SH. Microencapsulation of lipid nanoparticles containing lipophilic drug. J. Microencapsul. 20, 489-496 (2003). Doi:10.1080/ $\underline{0265204031000093032}$

22. Emerich DF. Nanomedicine-prospective therapeutic and diagnosticapplications. Expert Opin Biol Ther. 5, 1 - 5 (2005). Doi:10.1517/14712598.5.1.1

23. Siekmann B, Westesen, K. Melt-homogenized solid lipid nanoparticles stabilized by the nonionic surfactant tyloxapol - I. Preparation and particle size determination. Pharmacol. Lett. $\quad 3, \quad 194-197$ DOI:10.5138/ijap.2010.0976.1055.01027

24. Tomalia DA, H. Baker, J. Dewald, M. Hall, et al. A new class of polymers: Starburstdendritic macromolecules. Polym. J. 17, 117132 (1985). DOI: 10.1295/polymj.17.117 
25. Tomalia DA, H. Baker, J. Dewald, M. Hall, et al. Dendritic macromolecules: Synthesis of starburst dendrimers, Macromolecules. 19, 2466-2468 (1986). DOI: 10.1021/ $\underline{\mathrm{ma} 00163 \mathrm{a} 029}$

26. Newkome GR, Yao Z, Baker GR, et al. Micelles, Part 1: Cascade molecules-A new approach to micelles. J. Org. Chem. 50,20032004 (1985). DOI: 10.1021/jo00211a052.

27. Tomalia DA, Naylor AM, GoddardWA. Starburst dendrimers: Molecular-level control of size, shape, surface chemistry, topology, and flexibility from atoms to macroscopic matter. Angew. Chem. Int. Ed. Engl. 29, 138175 (1990). DOI: 10.1002/anie. 199001381

28. Hawker CJ, Frechet MJ. Preparation of polymers with controlled molecular architecture. A new convergent approach to dendritic macromolecules. J Am Chem Soc. 112, 7638-7647 (1990). DOI: $10.1021 / \mathrm{ja} 00177 \mathrm{a} 027$

29. Tomalia D.A \& Frechet J.M. J, “'Discovery of dendrimers and dendritic polymers: A brief historical perspective,' J. Polym. Sci. A: Polym. Chem. 40, 2719-2728 (2002). DOI: $10.1002 /$ pola.10301

30. Malik N, Wiwattanapatapee R, Klopsch R, et al. Dendrimers: Relationship between structure and biocompatibility in vitro, and preliminary studies on the biodistribution of 125I-labelled polyamidoamine dendrimers in vivo,. J Control Release. 65, 133-148 (2000). Haririan I, Shafiee-Alavidjeh M, Khorramizadeh MR et al. Anionic linearglobular dendrimer-cis-platinum [II] conjugates promote cytotoxicity in vitro against different cancer cell lines. Int J Nanomedicine. 5, 63-75 (2010). DOI: $\underline{10.1007 / \mathrm{nm} 02568093}$

31. Misselwitz B, H. Schmitt-Willich H, Ebert W, Frenzel T, Weinmann HJ. Pharmacokinetics of Gadomer-17: a new dendritic magnetic resonance contrast agent,. Magma. 12, 128134 (2001). DOI: 10.1007/BF02668094

32. Wu C.C, Brechbiel M.W, Kozak R.W, "Metal-chelate-dendrimer-antibody constructs for use in raDOIimmunotherapy and imaging," Bioorg. Med. Chem. Lett. 4, 449454 (1994).
33. Ou MH, Chen YM, Chang YH, Lu WK, Wang YM. Synthesis, complexation and water exchange properties of Gd(III)-TTDA-mono and bis(amide) derivatives and their binding affinity to human serum albumin. Dalton Trans. 112, 2749-2755 (2007). DOI: $\underline{10.1031 / \mathrm{mt} 00163 \mathrm{a} 029}$

34.http://www.fda.gov/cder/drug/infopage/dtpa/Q and A_DTPA.htm

35. Sato I, Tsuda S. Removal of $65 \mathrm{Zn}$ from mouse body by isotopic dilution and by DTPA chelation. J Vet Med Sci. 70:213 (2008).

36. Taylor DM, Hodgson SA, Stradling N. MADOR: a new tool to calculate decrease of effective doses in human after DTPA therapy. Radiat Prot Dosimetry.127,469 (2007).

37. Brasch RC, Weinmann HJ, Wesbey GE. Dendrimer and Imaging. Am J Roentgenol. 142, 625-628 (1984). DOI:10.1016/ j.ejmp.2007.05.001

38. Geraldesa C.F.G.C \& Laurent S. Classification and basic properties of contrast agents for magnetic resonance imaging. Contrast Media Mol. Imaging. 4, 1-23 (2009). Doi: 10.1021/jo00211a052.

39. Ardestani MS .Jabbari Arabzadeh A .Heidari $\mathrm{Z}$ et al. Novel and facile methods for the synthesis of DTPA-mono-amide:a new completely revised strategy in raDOIpharmaceuticalchemistry; J RaDOIanal Nucl Chem 283, 447-455 (2010). DOI: 10.1007/s10967-009-0414-y

40. J. Porath and P. Flodin. chromatography gel filtration Nature. 183, 1657 (1959). Doi:10.1038/1831657a0

41. Vaughan MF. Chromatography gel - filtration , Nature. 188, 55 (1960). Doi:10.1038/188055a0

42. Moore JC. Chromatography gel - filtration. Polymer Sci. A.21, 835 (1964).

43. Determann H. Gelchromatographie, Springer Verlag, Berlin, Heidelberg, New York, (1967). DOI: 10.1002/ange.19680801232

44. Freid B \& Sherma J. Thin-Layer Chromatography, Fourth Edition,revised and expanded, Marcel Dekker Inc., New York Basel, 499 (1999). DOI: 10.1007/mri02568054

45. http://orgchem.colorado.edu/hndbksupport/TL C/TLC.html 
46. http://www.chromatography-online.org/

47. http://www.chemistry.msu.edu/

48. www.malvern.com/process

49. Odlyha M, Theodorakopoulos C, de Groot J, Bozec L,.Horton M, Thermoanalytical (macro to nanoscale) techniques andnon-invasive spectroscopic analysis for damage assessment ofparchment, in: Improved Damage Assessment of Parchment, IDAPEC Research report . 18 : 73-85 (2010). DOI:10.1016/ j.idapec. 2010.05.098

50. Larsen $\mathrm{R}$ (Ed.). Improved Damage Assessment of Parchment,IDAP EC Research report. No. 18: 101-111 (2010).

51. Bhatia SN, Balis UJ, Yarmush ML, Toner M. Effect of cell-cell interactions in preservation of cellular phenotype: cocultivation of hepatocytes and nonparenchymal cells. Faseb J. 13, 1883-1900 (1999).

52. Rheinwald JG, Green H. Serial cultivation of strains of human epidermal keratinocytes: the formation of keratinizing colonies from single cells. Cell. 6, 331-343 (1975).

53. Wodicka L, Dong H, Mittmann M, et al. Genome-wide expression monitoring in Saccharomyces cerevisiae. Nat Biotechnol . 15,1359-1367 (1997). Doi:10.1038/nbt12971359.

54. Newton, D.J., Wang, R.W. Lu, A.Y. Cytochrome P450 inhibitors. Evaluation of specificities in the in vitrometabolism of therapeutic agents by human liver microsomes. Drug Metab Dispos 23, 154-158 (1995).

55. Adeli M, Mirab N, Shafiee Alavidjeh M, Sobhani Z, Atyabi F. Carbon nanotubes-graftpolyglycerol: Biocompatible hybrid material in nanomedicine. Polymer. 50,3528-3536 (2009). DOI: 10.2009/nmvi01563084
56. Mosmann T. Rapid colorimetric assay for cellular growth and survival: application for proliferation and cytotoxicity assay. J Immunol Methods. 65,55-63 (1983).

57. Malik N, Evagorou EG, Duncan R. Dendrimer-Platinate: a novel approach to cancer chemotherapy. Anti-cancer Drugs. 10, 767-776 (1999). DOI: 10.1999/acd/3212442

58. Fastrez J. Phage Lysozymes In: Lysozymes-model enzymes in biochemistry and biology, Pierre Jollès editor, Birkhäuser. 35-64 (1996).

59. Scholar E M, Pratt WB. The antimicrobial drugs, Oxford University Press US, 2nd ed; 61-64 (2000).

60. Skoog DA, West DM, Holler FJ. Fudamentals of AnalyticalChemistry . Anal. 22, 201-221 (1992).

61. Kenkel J. Analytical Chemistry for Technicians. Anal. 24,1103-1117 (1994).

62. Cheng Y \& Prusoff WH "Relationship between the inhibition constant (K1) and the concentration of inhibitor which causes 50 percent inhibition (I50) of an enzymatic reaction". Biochem Pharmacol . 22, 3099-108 (1973).

63. Robinson SF; Marks MJ; Collins AC . Inbred mouse strains vary in oral self-selection of nicotine". Psychopharm.124, 332-339 (1996).

64. Raymond, KN \& Pierre, VC. Next generation, high relaxivity gadolinium MR1 agents. Bioconjugate Chem, 16, 3-8. (2005).

65. Platzek J, Mareski P, Niedballa U, Raduchel B. Process for the production of monoamides of DTPA. United States Patent No: US 6080785. (2004). 